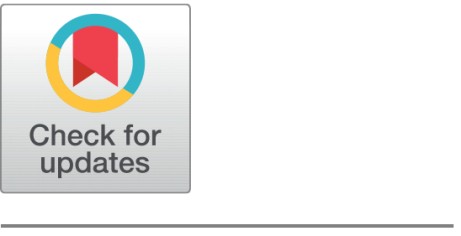

G OPEN ACCESS

Received: 16-04-2020

Accepted: 23-04-2020

Published: 23-05-2020

Editor: Dr. Natarajan Gajendran

Citation: Quang HT, Lan TT, Hai TTH, Yen PTH, Van TQK, Tung HT, Binh MN, Son NKH, Linh NQ, Tram NDQ (2020) Genetic diversity and toxic genes analysis of vibrio spp. isolated from white leg shrimp and marine fishes cultured in Tam Giang lagoon in Thua Thien Hue province, Vietnam. Indian Journal of Science and Technology 13(13): 1412-1422. https://doi.org/ 10.17485/IJST/v13i13.161

*Corresponding author. Nguyen Duy Quynh Tram

University of Agriculture and Forestry, Hue University, Hue, 530000, Vietnam

ndqtram@hueuni.edu.vn

Funding: This study was financial supported by the grant from

Vietnam Ministry of Education and Training (Project No.

CT-2018-DHH-01)

Competing Interests: None

Copyright: @ 2020 Quang, Lan, Hai, Yen, Van, Tung, Binh, Son, Linh, Tram. This is an open access article distributed under the terms of the Creative Commons Attribution License, which permits unrestricted use, distribution, and reproduction in any medium, provided the original author and source are credited.

Published By Indian Society for Education and Environment (iSee)

\section{Genetic diversity and toxic genes analysis of vibrio spp. isolated from white leg shrimp and marine fishes cultured in Tam G iang lagoon in Thua Thien Hue province, Vietnam}

\author{
Hoang Tan Quang1, Tran Thuy Lan ${ }^{1}$, Truong Thi Hong Hai ${ }^{1}$, Pham Thi Hai \\ Yen ${ }^{2}$, Tran Quang Khanh Van'2, Ho Thi Tung², Mac Nhu Binh², \\ Nguyen Khoa Huy Son ${ }^{2}$, Nguyen Quang Linh ${ }^{3}$, Nguyen Duy Quynh Tram²*
}

1 Institute of Biotechnology, Hue University, Hue, 530000, Vietnam 2 University of Agriculture and Forestry, Hue University, Hue, 530000, Vietnam 3 Hue University, Hue, 530000, Vietnam

\section{Abstract}

Objective: This study was done to report the results of genetic diversity and toxic genes analysis of Vibrio pathogen isolated from white leg shrimp and marine fishes cultured in Thua Thien Hue province, Vietnam. Methods/statistical analysis: Pathogen Vibrio spp. were isolated from shrimps and fishes, and were identified by $16 \mathrm{~S}$ rRNA sequencing. The presence of toxin genes in Vibrio spp. strains were determined through the presence of genes encoding toxic proteins (pirAvp, pir$B v p, t / h, t d h$ and trh) based on specific primers for these genes. Genetic diversity of Vibrio strains was analysed by RAPD technique. Findings: A total of 120 Vibrio colonies from shrimps (with Acute Hepatopancreatic Necrosis Disease) and fishes (with hemorrhagic disease) cultured in Tam Giang lagoon in Thua Thien Hue, Vietnam were isolated. Of which, 14/54 strains from shrimps had pirAvp and pirBvp genes and 18/66 strains from fishes had th gene, and none of Vibrio strains had $t d h$ and trh genes. Randomly amplified polymorphic DNA (RAPD) analysis of 36 Vibrio samples showed the 148 polymorphic DNA fragments from ten random primers. The genetic diversity is high within studied species. In there, $V$. parahaemolyticus has the highest diversity level $(h=0.1645$ and $\mathrm{l}=0.2695)$ while $V$. shilonii is lowest $(h=0.0136)$ and $\mathrm{l}=0.0207)$. The degree of genetic differentiation among species is also high (Gst $=0.4827)$. Genetic identity between $V$. parahaemolyticus and V. vulnificus (0.9545) is highest while between $V$. shilonii and $V$. harveyi $(0.7416)$ is lowest. The dendrogram also showed that $V$. parahaemolyticus is closely related to $V$. vulnificus whereas V. shilonii and $V$. harveyi have large distance. Application/improvements: This study is aimed to provide scientific data as the basis for the study and production of rapid diagnostic kits in the future.

Keywords: AHPND; Genetic diversity; RAPD; toxic genes; Vibrio; Vietnam 


\section{Introduction}

Vibrio spp. are found in all over the world in marine and estuarine environments. In fish, this genus is present as a part of the normal intestinal microflora. Some Vibrio spp. (such as V. anguilarum, V. harveyi, and V. parahaemolyticus) can cause dangerous diseases in shrimp ${ }^{(1)}$.

In shrimp, Acute Hepatopancreatic Necrosis Disease (AHPND) has caused remarkable mortality (up to 100\%) in populations of shrimp cultured in South East Asian and Latin American countries. This disease is referred to as early mortality syndrome (EMS). AHPND is caused by several Vibrio species, which secretes proteins similar to Photorhabdus insect-related (Pir) toxins (PirAvp and PirBvp $)^{(1,2)}$. Vibrio spp. are also mainly pathogenic to brackish water and marine fish. The distribution of vibriosis is worldwide and causes economic loss to the aquaculture industry ${ }^{(3)}$.

The Tam Giang lagoon in Thua Thien Hue province of Vietnam is the biggest lagoon in the Southeast Asia. Aquaculture has developed in the Tam Giang Lagoon since the late 1970s, and has become the most important livelihood activity since the early 1990s. However, aquaculture production decreased continuously since 2009 until now. The main reason is because of the disease outbreak, natural disasters, climate change and the environment issues, especially water pollution has serious impacts on the health of the aquatic animals. In addition, the increased intensity of the flood seriously affects aquaculture production through changing of water quality and salinity. Many farmers lost their production due to serious Vibrio bacterial and viral shrimp diseases related to increasing water temperature ${ }^{(4,5)}$.

Randomly amplified polymorphic DNA (RAPD) is a PCR-based genotyping technique, using random primers to detect changes in the DNA sequence. According to Behura et al (2015), RAPD was a reliable and fast technique for discriminating between the species of Vibrio, therefore, this is a powerful tool for these prawn pathogens study ${ }^{(6)}$.

In Thua Thien Hue, to our knowledge there is limited published data available on the genetic diversity and toxic genes analysis of Vibrio isolated from white leg shrimp and marine fishes cultured. This study is therefore aimed to provide scientific data as the basis for the study and production of rapid diagnostic kits.

\section{Materials and Methods}

\subsection{Sample collection}

Seventy samples of shrimp (body weight of $0,64 \mathrm{~g} \pm 0,22$ and length of 4,37 $\mathrm{cm} \pm 0.29$ Hepatopancreatic Necrosis Disease syndromes were collected from white-leg shrimp (Litopenaeus vannamei) at farms in Dien Hai $(\mathrm{n}=8)$, Dien Mon $(\mathrm{n}=12)$ and Dien Huong ( $\mathrm{n}=15)$ communes (Phong Dien district), Phu Thuan town $(\mathrm{n}=15)$ (Phu Vang district) and Loc Binh commune $(\mathrm{n}=20)$ (Phu Loc district) ( Figures 1 and 2 ). Sampling was done with live shrimps which showed signs of pathology: stopped eating; swim slowly; pale, atrophy, and toughness in the liver and empty intestine. The outer surface of the shrimp body was disinfected with $70^{\circ}$ alcohol before bacterial isolation. Vibrio sp. was isolated from their liver and pancreas, then samples were cultured on TCBS medium (Thiosulfate Citrate Bile Sucrose Agar) at $30^{\circ} \mathrm{C}$ for 24 hours.

Thirty-two samples of fishes including seabass (Lates calcarifer, $\mathrm{n}=12$ ), red drum (Sciaenops ocellatus, $\mathrm{n}=15$ ) and grouper (Epinephelus fuscoguttatus, $\mathrm{n}=5$ ) with haemorrhage were collected from cages (in Hai Duong communes and Thuan An town, Phu Vang district) had typical signs: stopped eating, and swimming slowly (Figure 1 and 2). The external signs of three fish species were hemorrhage on body, abdomen, fin erosion, tailless condition and protruding eyes. The fish was disinfected with $70^{\circ}$ alcohol and cleaned, using the sterile implants for sampling bacteria from the hemorrhage areas on the body and bacterial samples in the heart, liver, kidneys, intestines, spleen and brain for culturing on TCBS medium, incubated at $30^{\circ} \mathrm{C}$ for 24 hours.

After 24 hours, the development of colonies was checked. The types of colonies on plates were distinguished based on color, shape and size of colonies. The dominant colonies were transferred to TCBS medium to select pure colonies for further studies.

A total of 120 Vibrio spp. colonies were isolated on TBSC medium from shrimps (54 colonies) and fishes (66 colonies) in Thua Thien Hue province, Vietnam for toxic genes determination.

\subsection{DNA isolation}

Vibrio colonies were cultured in alkaline saline peptone water (ASPW) with $2 \%$ peptone and $2 \% \mathrm{NaCl}, \mathrm{pH} 8.6$, shaking speed of $180 \mathrm{rpm}$ for 18 hours at $30^{\circ} \mathrm{C}$. Cells were collected by centrifugation at $13,000 \mathrm{rpm}$ for 1 minute at $4^{\circ} \mathrm{C}$. Total genomic DNA was extracted using AquaPure Genomic DNA Isolaton Kit (Cat. 732-6340, Bio-rad) according to the manufacturer's instructions and then stored at $4^{\circ} \mathrm{C}$. Total DNA concentration was determined using a photo spectrometer at $260 / 280 \mathrm{~nm}$. Genomic DNA was diluted to a final concentration of $50 \mathrm{ng} / \mu \mathrm{L}$ for PCR amplification. 


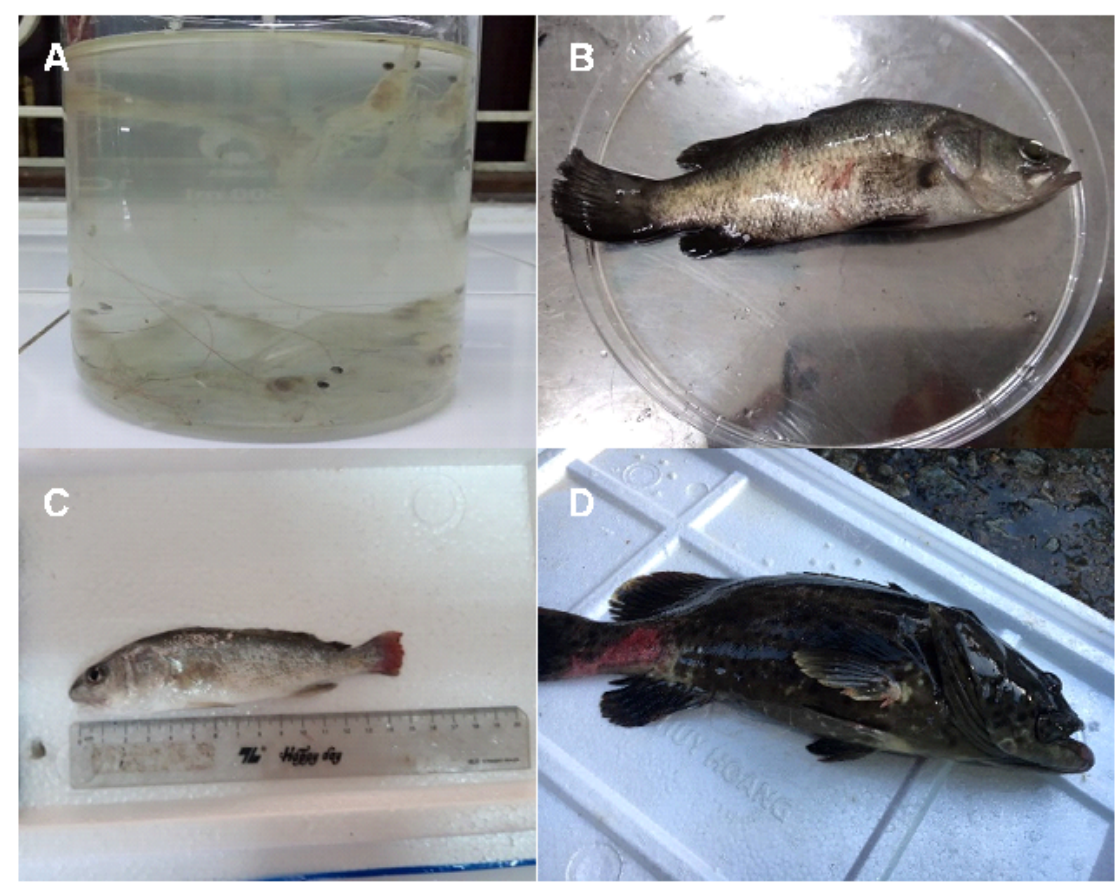

Fig 1. Samples for Vibrio isolation. A. Litopenaeus vannamei, B. Lates calcarifer, C. Sciaenops ocellatus, D. Epinephelus fuscoguttatus.

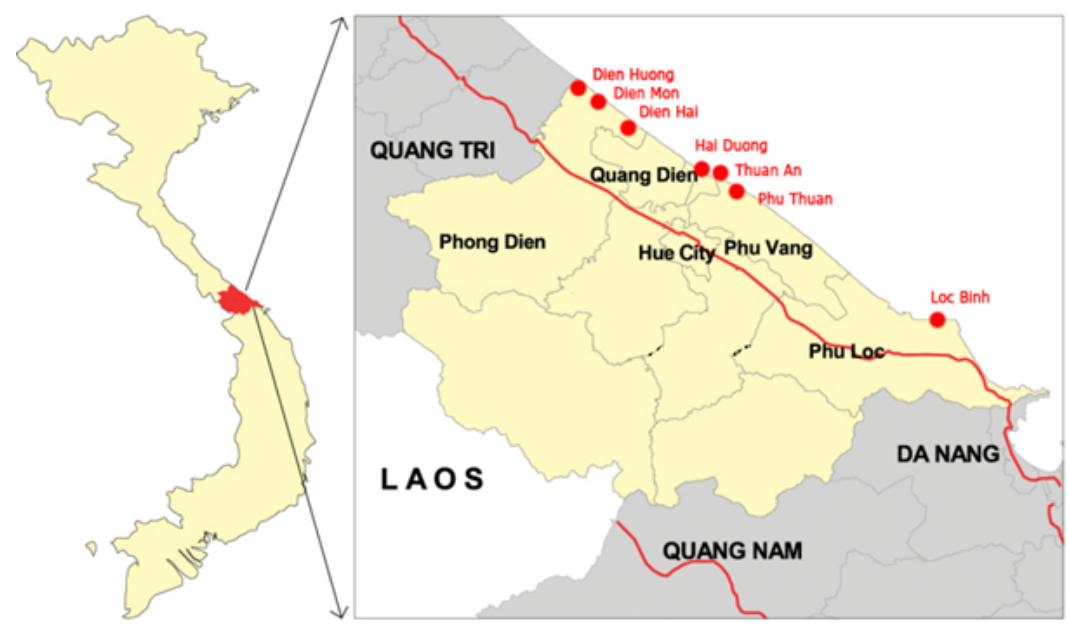

Fig 2. Map of samples collection (red spots)

\subsection{Determination of toxin gene}

The presence of toxin genes in Vibrio spp. strains were determined through the presence of genes encoding toxic proteins (pirAvp, pirBvp, th, $t d h$ and $t r h$ ) based on specific primers for these genes ( Table 1).

PCR procedure: $50 \mathrm{ng}$ of total DNA, $10 \mathrm{pmol}$ of each primer, $6 \mu \mathrm{L} 2 \times$ Go Taq Green Master Mix (M7502, Promega, USA), and sterile distilled water (total volume of $12 \mu \mathrm{L}$ ). PCR amplification was performed in MJ Mini ${ }^{\mathrm{TM}}$ Thermal Cycler (Bio-Rad, USA) as follow: $95^{\circ} \mathrm{C}$ for 10 minutes; followed by 30 cycles at $95^{\circ} \mathrm{C}$ for 30 seconds, $53^{\circ} \mathrm{C}$ for 30 seconds, and $72^{\circ} \mathrm{C}$ for 1 minute; last cycle was $72^{\circ} \mathrm{C}$ for 10 minutes. PCR products were used for electrophoresis on $0.8 \%$ agarose gel, stained by SafeView ${ }^{\mathrm{TM}}$ Classic Nucleic Acid Stain (Applied Biological Materials Inc., Canada) and determined by Ultra Slim LED Illuminator system. 
Table 1. Sequence of primers

\begin{tabular}{|c|c|c|c|c|c|}
\hline Genes & Primer names & Nucleotide sequences & & Size (bp) & References \\
\hline pirAvp & VpPirA-284 & $\begin{array}{l}\text { 5'-TGACTATTCTCACGATTGGACTG-3' } \\
\text { CACGACTAGCGCCATTGTTA-3' }\end{array}$ & $5{ }^{\prime}-$ & 284 & (1) \\
\hline $\operatorname{pirBvp}$ & VpPirB-392 & $\begin{array}{l}\text { 5’-TGATGAAGTGATGGGTGCTC-3' } \\
\text { TGTAAGCGCCGTTTAACTCA-3’ }\end{array}$ & 5 - & 392 & (1) \\
\hline tlh & $\mathrm{tl}$ & $\begin{array}{l}\text { 5'AAAGCGGATTATGCAGAAGCACTG-3' } \\
\text { GCTACTTTCTAGCATTTTCTCTGC-3' }\end{array}$ & 5 - & 450 & (7) \\
\hline trh & L-trh R-trh & $\begin{array}{l}\text { 5'TTGGCTTCGATATTTTCAGTATCT-3' } \\
\text { CATAACAAACATATGCCCATTTCCG-3' }\end{array}$ & 5 - & 410 & (5) \\
\hline$t d h$ & L-tdh R-tdh & $\begin{array}{l}\text { 5'-GTAAAGGTCTCTGACTTTTGGAC-3' } \\
\text { TGGAATAGAACCTTCATCTTCACC-3' }\end{array}$ & $5 ’$ & 245 & (5) \\
\hline
\end{tabular}

\subsection{Vibrio identification}

Vibrio strains with pirAvp and pirBvp genes (from shrimps) or th, $t d h$ and trh genes (from fishes) were identification based on the sequencing of $16 \mathrm{~S}$ rDNA genes (Table 2 and 3). The total DNA was used as a template for the $16 \mathrm{~S}$ rDNA amplification using the primer pair of 27F (5'-AGAGTTTGATCCTGGCTCAG-3') and 1492R (5'-GGTTACCTTGTTACGACTT-3'). PCR products are purified and sequenced at Firstbase company (Malaysia). The nucleotide sequences of 16S rDNA were used for species identification with BLAST tool on Genbank. Phylogenetic tree was built with MEGA X software.

\subsection{Genetic diversity}

Genomic DNA were used as template for RAPD analysis, including 14 strains with pirABvp genes, 18 strains with th gene and 4 non-toxic genes strains (Table 2 and 3). PCR reactions were carried out according to Quang et al (2016). Each reaction contained $10 \mu 12 \times$ PCR master mix (GoTaq Green Master Mix 2X, Promega, USA), 20 pmol each primers and 50 ng genomic DNA in a $20 \mu \mathrm{L}$ final volume. Amplification was performed in a thermocycler (SimpliAmp, ThermoFisher Scientific, USA) under the following conditions: $3 \mathrm{~min}$ at $95^{\circ} \mathrm{C}$; followed by 42 cycles for $1 \mathrm{~min}$ of denaturing at $92^{\circ} \mathrm{C} ; 1 \mathrm{~min}$ of annealing at $36^{\circ} \mathrm{C}$ and a 2 min extension at $72^{\circ} \mathrm{C}$; a final extension for $10 \mathrm{~min}$ at $72^{\circ} \mathrm{C}$. PCR products were separated on a $1.4 \%$ agarose gel for $5 \mathrm{hr}$ at $40 \mathrm{~V}^{(8)}$. Samples with lack of bands in agarose gel were replicated twice to get confirmation. Ten random decamer oligonucleotide primers (Operon Technologies, USA) were selected for evaluation (Table 4).

PCR-RAPD amplicons were scored as presence (1) or absence (0) of a band in each sample. The sizes of the RAPD markers were estimated by using the DNA size standard (GeneRuler 1kb DNA Ladder, Thermo Scientific). The genetic identity and genetic distance between populations were expressed using Nei's (1972) genetic distance ${ }^{(9)}$. Genetic parameters were calculated as the total genotype diversity in populations (Ht), total genotype diversity within populations $(\mathrm{Hs})$, mean coefficient of gene differentiation (Gst), and estimate of gene flow (Nm); number of polymorphic bands, observed number of alleles (na), effective number of alleles (ne), Nei's (1973) gene diversity (h), Shannon's information Index (I) for RAPD data using the POPGENE software ver. $1.31^{(10)}$.

\section{Results}

\subsection{Isolation of pathogenic Vibrio}

From 120 Vibrio samples, we found that 14 strains (from shrimps) and 18 strains (from fishes) had pirAvp and pirBvp genes or tlh gene, respectively ( Tables 2 and 3). V. parahaemolyticus is the most popular species that cause diseases in shrimp and fish, and has both pirABvp and th genes. V. shilonii displayed only in shrimp while V. vulnificus, V. harveyi and V. cholerae appeared only in fish.

In shrimp, the pVPA3-1 plasmid causes AHPND was identified in V. parahaemolyticus strain 13-028/A3, it consists of genes that encode mobilization proteins, replication enzymes, virulence-associated proteins, and proteins similar to Pir toxins. These Pir toxin-like proteins are encoded by 2 genes (pirA- and pirB-like), also known as pirAvp and pirBvp genes ${ }^{(1)}$. In Thua Thien Hue province, 14/54 samples from shrimp had pirABvp genes (25.93\%), including V.parahaemolyticus, V. shilonii, V. communis and V. furnissii species. The bacterium V. shilonii was found in the first time in Vietnam. V. shilonii had been found to be a cause of bleaching in the coral Oculina patagonica ${ }^{(11)}$, in recent paper, V. shilonii caused AHPND was found in Ecuador ${ }^{(1)}$

In fish, the majority of Vibrio strains isolated were not pathogenic. The pathogenic strains are those that produce thermostable 
Table 2. Isolation of pathogenic Vibrio isolates from shrimp

\begin{tabular}{|c|c|c|c|c|c|c|}
\hline & Sample & Strain & Colonies morphology & Location & Genes & \\
\hline & & & & & pirA & $\operatorname{pir} B$ \\
\hline 1 & VT19 & $\begin{array}{l}\text { V. parahaemolyticus TX07- } \\
3 / 3\end{array}$ & Green, small center, serrated edges & Phu Thuan & + & + \\
\hline 2 & VT23 & V. shilonii TX05-3/3 & Green, big center, non-round edges & Phu Thuan & + & + \\
\hline 3 & VT26 & V. shilonii TX03-3/3 & Green, non-center, round edges & Phu Thuan & + & + \\
\hline 4 & VT27 & V. shilonii $\mathrm{TX} 02-3 / 3$ & $\begin{array}{l}\text { Green, big center, round, medium } \\
\text { from green to yellow }\end{array}$ & Phu Thuan & + & + \\
\hline 5 & VT29 & V. shilonii $\mathrm{TX} 01-3 / 3$ & Green, dark center, round & Phu Thuan & + & + \\
\hline 6 & VT33 & V. shilonii TV02-3/3 & $\begin{array}{l}\text { Yellow, big center, round, medium } \\
\text { from green to yellow }\end{array}$ & Phu Thuan & + & + \\
\hline 7 & VT34 & $\begin{array}{l}\text { V. parahaemolyticus } 29 \mathrm{X} 2 \text { - } \\
13 / 5\end{array}$ & $\begin{array}{l}\text { Green, round, smooth, } 2 \mathrm{~mm} \text { diame- } \\
\text { ter }\end{array}$ & Dien Huong & - & - \\
\hline 8 & VT41 & $\begin{array}{l}\text { V. parahaemolyticus } \mathrm{K} 31-\mathrm{X}- \\
13 / 6 / 2019\end{array}$ & $\begin{array}{l}\text { Green to yellow, round, smooth, } 2 \\
\text { mm diameter, medium from green to } \\
\text { yellow }\end{array}$ & Dien Huong & + & + \\
\hline 9 & VT44 & $\begin{array}{l}\text { V. parahaemolyticus } \mathrm{K} 39-\mathrm{X}- \\
13 / 6\end{array}$ & $\begin{array}{l}\text { Green to yellow, round, smooth, } 2 \mathrm{~mm} \\
\text { diameter }\end{array}$ & Dien Huong & + & + \\
\hline 10 & VT47 & $\begin{array}{l}V . \text { communis R-PD-K4-V- } \\
13 / 6\end{array}$ & $\begin{array}{l}\text { Yellow, round, smooth, } 2 \mathrm{~mm} \text { diame- } \\
\text { ter, medium from green to yellow }\end{array}$ & Dien Mon & + & + \\
\hline 11 & VT56 & $\begin{array}{l}\text { V. parahaemolyticus } \mathrm{PD}-\mathrm{K} 1- \\
10 / 6\end{array}$ & $\begin{array}{l}\text { Green, round, smooth, } 2 \mathrm{~mm} \text { diame- } \\
\text { ter }\end{array}$ & Dien Mon & - & - \\
\hline 12 & VT59 & $\begin{array}{l}\text { V. parahaemolyticus R-PD- } \\
\text { K3-10/6 }\end{array}$ & $\begin{array}{l}\text { Yellow, round, } \\
1.5 \mathrm{~mm} \text { diameter, medium from green } \\
\text { to yellow }\end{array}$ & Dien Mon & + & + \\
\hline 13 & VT62 & $\begin{array}{l}\text { V. parahaemolyticus R-PD- } \\
\text { K3-10/6 }\end{array}$ & $\begin{array}{l}\text { Green, round, smooth, } 2 \mathrm{~mm} \text { diame- } \\
\text { ter }\end{array}$ & Dien Mon & + & + \\
\hline 14 & VT65 & V. furnissii R-K39-13/6 & Yellow, round, $2 \mathrm{~mm}$ diameter & Dien Huong & + & + \\
\hline 15 & VX01 & V. parahaemolyticus VX01 & $\begin{array}{l}\text { Green, viscous, round, smooth, } 2 \mathrm{~mm} \\
\text { diameter }\end{array}$ & Dien Huong & + & + \\
\hline 16 & K5 & V. parahaemolyticus $\mathrm{K} 5$ & Green, round, convex & Dien Huong & + & + \\
\hline
\end{tabular}

direct haemolysin (TDH) toxin. TDH is an enzyme that lyses human red blood cells on Wagatsuma blood agar plates, which is referred to as the Kanagawa phenomenon positive. Another toxin produced by Kanagawa phenomenon negative Vibrio strains is the TDH-related hemolysin (TRH) toxin encoded by trh gene ${ }^{(12)}$. Thermolabile hemolysin (TLH) is an another Vibrio enterotoxin that cause blood cell lysis in infected fish, TLH is encoded by th gene ${ }^{(13)}$. In this study, 18/66 strains had th gene (27.27\%), including V. vulnificus, V. harveyi, V. parahaemolyticus, V. cholerae, V. brasiliensis, V. fluvialis and V. natriegens. None of Vibrio strains had $t d h$ and $t r h$ genes, so maybe hemorrhagic disease in fish at Thua Thien Hue province was caused by TLH toxin. Our study is in accordance to report by Chosin et al. (2015), none of the eight AP-positive AHPND V. parahaemolyticus strains possesses the genes for the conventional virulence factors affecting humans, such as $t d h$, $t r h$ and type III secretion system $2^{(14)}$. In Bangladesh, Ahmmed et al. (2019) found th, pirA and pirB genes from two AHPND positive V. parahaemolyticus strains isolated from shrimp (Penaeus monodon) ${ }^{(15)}$.

The previous studies in Malaysia showed that the most virulent of the non-cholera vibrios (V. vulnificus) have various virulence factors that facilitate the development of clinical disease ${ }^{(16)}$. V. vulnificus also have been implicated in fish diseases such as septicemia ${ }^{(3)}$. In our study, V. vulnificus $(6 / 18)$ was the most popular patogen species in fish.

Vibrio spp. that caused disease in shrimp and marine fish are widely distributed in brackish and saline waters worldwide. They exist in the aquatic environment and can be harmful to shrimp and fish in favorable conditions.

In shrimp, the presence of Vibrio spp. such as V. parahaemolyticus, V. alginolyticus, V. vulnificus, etc. are likely to cause AHPND $^{(17)}$. The disease has caused huge losses, high mortality, and a very high risk for shrimp farming from 2010 to the 


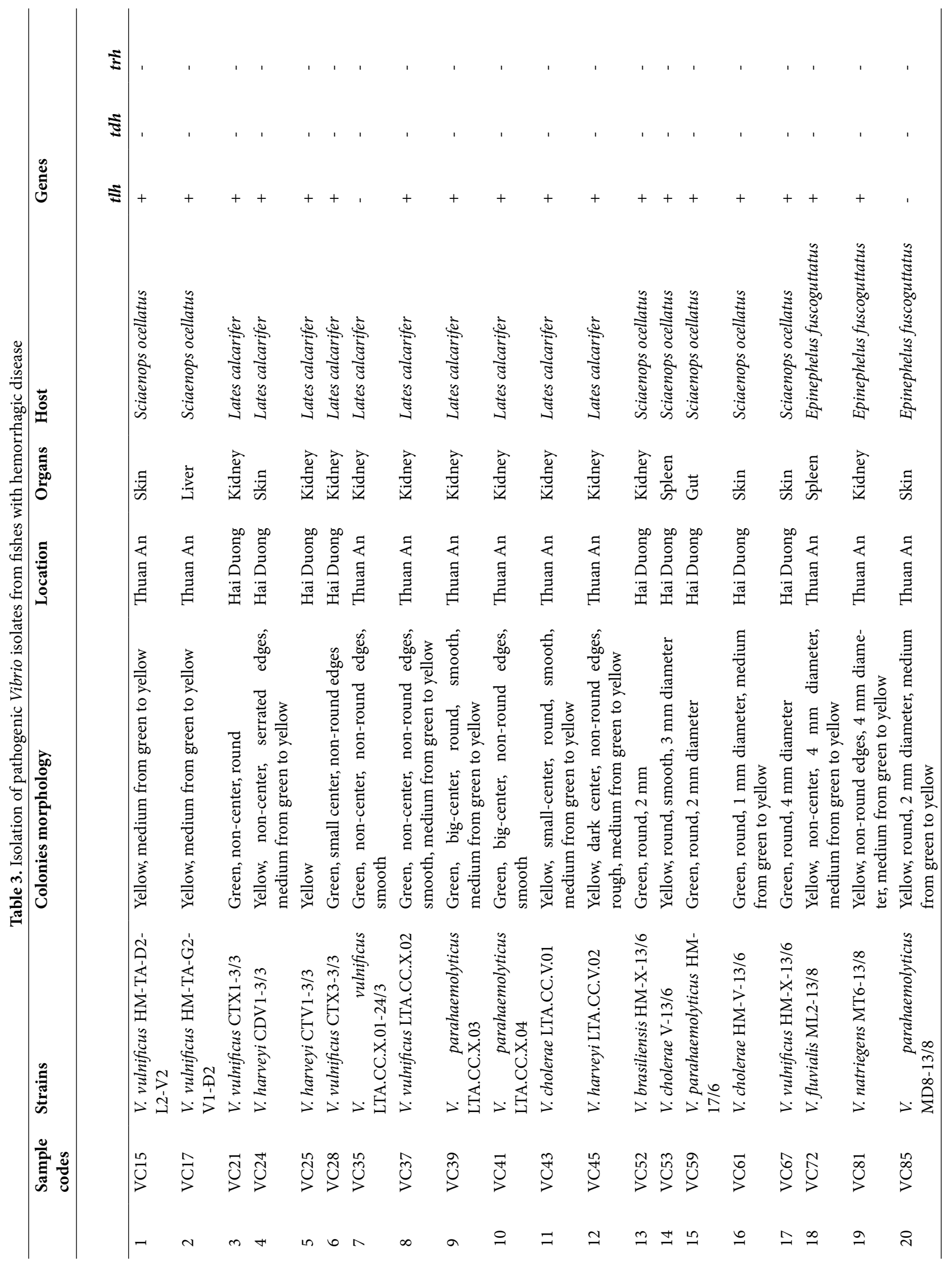


present. Clinical signs of the disease include an empty gastrointestinal tract, an opaque stomach, a white atrophic pancreas, lethargic shrimps, anorexia and soft shells ${ }^{(18)}$. Diseases caused by Vibrio bacteria appear all year round but often out break when high water temperature and in high salinity waters, somehow the disease can still occur in the estuaries or for a number of freshwater fish species.

Although bacteria can be infected in different parts, they often attack the heart and muscles of the fish. Because they have a strong ability to attack the muscular system, hence it is very serious and difficult to treat, bacteria can cause chronic diseases in adults. If the disease occurs acute, the consequences of damage are very heavy.

In fish larvae, fry or fingerlings, when seriously infected they can be killed up to $50 \%$. In adult fish, the rate of damage is lower but the fish will develop anorexia or stop eating or ceases in growth and at harvest it is possible to observe necrotic wounds on the skin and muscles of the fish. When the fish were infected with Vibrio, fish eats less or stops eating, they swim on the surface layer and around the cage edge. On the fish body, often appear various small reddish ulcers with the skin bulging surrounding it and a lot of viscous. The internal organs, liver, kidney, spleen with hemorrhage would have occurred and empty gastrointestinal $\operatorname{tract}^{(5)}$.

Restrepo et al. (2018) reported that the gene transfer capacity of Vibrio species goes beyond the clade classification, creating new Vibrio pathogenesis and has major implications for the spread of emerging diseases ${ }^{(19)}$. In our study, ten Vibrio species contain toxic genes ( $p i r A$, pirB, and $t h$ ), they seem to be the results of gene transfer of among Vibrio species in Vietnam sea.

\subsection{RAPD analysis}

A total of 20 RAPD primers were assayed for their specificity in detecting Vibrio species, ten primers were highly reproducible and found suitable for use in RAPD-PCR. These selected primers generated total of 148 amplified bands, ranging in size from approximately 200 (OPB-18) to 4000 bp (OPB-01 and OPN-03), and the number of PCR products of each primer varied from 11 to 17 ( Table 4). All of bands were polymorphic (with a mean of 14.80 bands per primer). OPG-17 is the best primer for Vibrio with 100\% genotypes were amplified (15 bands) (Figures 3 and 4).

Table 4. Sequence of RAPD primer, band sizes, and number of amplified bands

\begin{tabular}{|c|c|c|c|c|}
\hline Primercode & Nucleotide sequence (5'-3') & $\begin{array}{l}\text { Number of amplification } \\
\text { genotypes }\end{array}$ & $\begin{array}{l}\text { Size range of amplified } \\
\text { bands }(\mathrm{bp})\end{array}$ & $\begin{array}{l}\text { Number of amplified } \\
\text { bands }\end{array}$ \\
\hline OPA-03 & AGTCAGCCAC & 32 & $250-3500$ & 15 \\
\hline OPA-11 & CAATCGCCGT & 35 & $350-3100$ & 16 \\
\hline OPB-01 & GTTTCGCTCC & 33 & $500-4000$ & 16 \\
\hline OPB-18 & CCACAGCAGT & 34 & $200-2500$ & 15 \\
\hline OPC-13 & AAGCCTCGTC & 31 & $320-3500$ & 13 \\
\hline OPD-02 & GGACCCAACC & 34 & $300-3300$ & 17 \\
\hline OPD-07 & TTGGCACGGG & 35 & $320-2700$ & 11 \\
\hline OPG-17 & ACGACCGACA & 36 & $320-3000$ & 15 \\
\hline OPN-03 & GGTACTCCCC & 30 & $350-4000$ & 13 \\
\hline OPN-06 & GAGACGCACA & 35 & $250-3000$ & 17 \\
\hline Overall & & & $200-4000$ & 148 \\
\hline Mean & & & & 14.80 \\
\hline
\end{tabular}

In this study, the percentage of polymorphic bands (PPB) of each population was ranged from $25.80 \%$ ( V. shilonii) to $100 \%$ (V.parahaemolyticus and V. vulnificus) (Table 5). The PPB of all samples was 79.08\%. The total amplicon among all Vibrio species varied from 45 (V. cholerae) to 105 (V. parahaemolyticus). V. shilonii had the different RAPD pattern from other Vibrio species in number of PCR amplicons (31), number of polymorphic loci (8), percentage of polymorphic bands (25.80\%) and number of specific loci (1).

\subsection{Genetic diversity}

Data for observed number of alleles (na), effective number of alleles (ne), Nei's (1973) genetic diversity (h), Shannon's information index (I), for all the Vibrio species were analyzed using ten RAPD primers and their respective values were found as $2.0000,1.2885,0.2046$, and 0.3435 , respectively (Table 6). V. shilonii displayed the lowest value of Nei's (1973) gene diversity $(\mathrm{h}=0.0136)$ and Shannon's information index $(\mathrm{I}=0.0207)$, whereas the highest population was $V$. parahaemolyticus $(\mathrm{h}=0.1645$ 


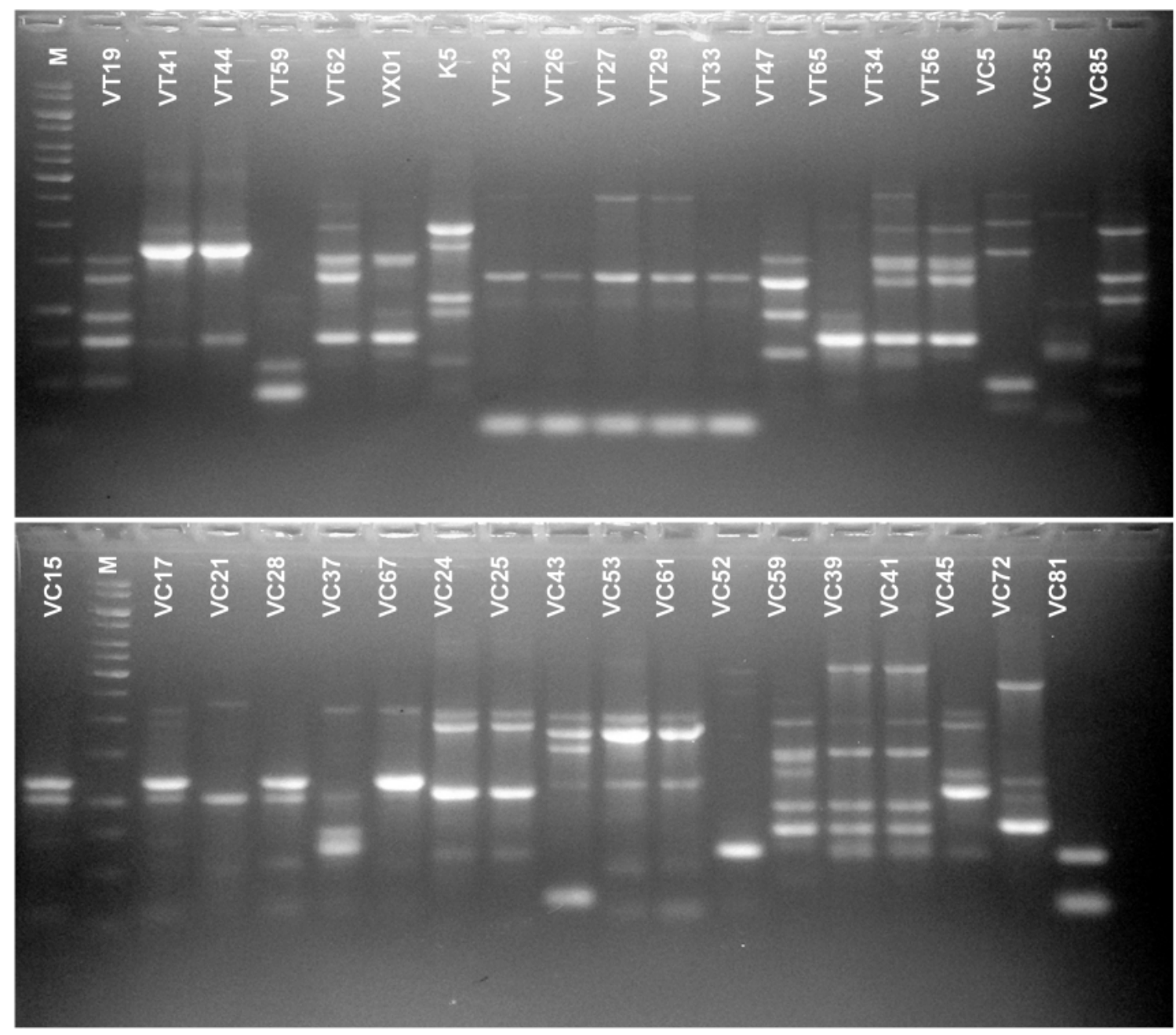

Fig 3. PCR products of OPG-17 primer of 36 samples. M. DNA molecular size marker (GeneRuler ${ }^{\mathrm{TM}}$ DNA $1 \mathrm{~kb}$ ladder, Thermo Fisher Scientific). Sample codes were located at the top of lane.

Table 5. Summary of PCR amplicons of Vibrio in Thua Thien Hue using RAPD markers

\begin{tabular}{|c|c|c|c|c|}
\hline Species & $\begin{array}{l}\text { Number of } \\
\text { PCR amplicons }\end{array}$ & $\begin{array}{l}\text { Number of polymor- } \\
\text { phic loci }\end{array}$ & $\begin{array}{l}\text { Percentage of polymor- } \\
\text { phic bands }\end{array}$ & Number of specific loci \\
\hline V. parahaemolyticus & 105 & 105 & 100 & 0 \\
\hline V. vulnificus & 61 & 61 & 100 & 0 \\
\hline V. shilonii & 31 & 8 & 25.80 & 1 \\
\hline V. harveyi & 55 & 42 & 76.36 & 3 \\
\hline V. cholerae & 45 & 33 & 73.33 & 0 \\
\hline Others $^{*}$ & 97 & 96 & 98.97 & 0 \\
\hline Mean & 65.67 & 57.5 & 79.08 & 0.67 \\
\hline Overall & & & & 4 \\
\hline
\end{tabular}

*Others: samples including V. communis, V. furnissii, V. brasiliensis, V. fluvialis and V. natriegens species. 

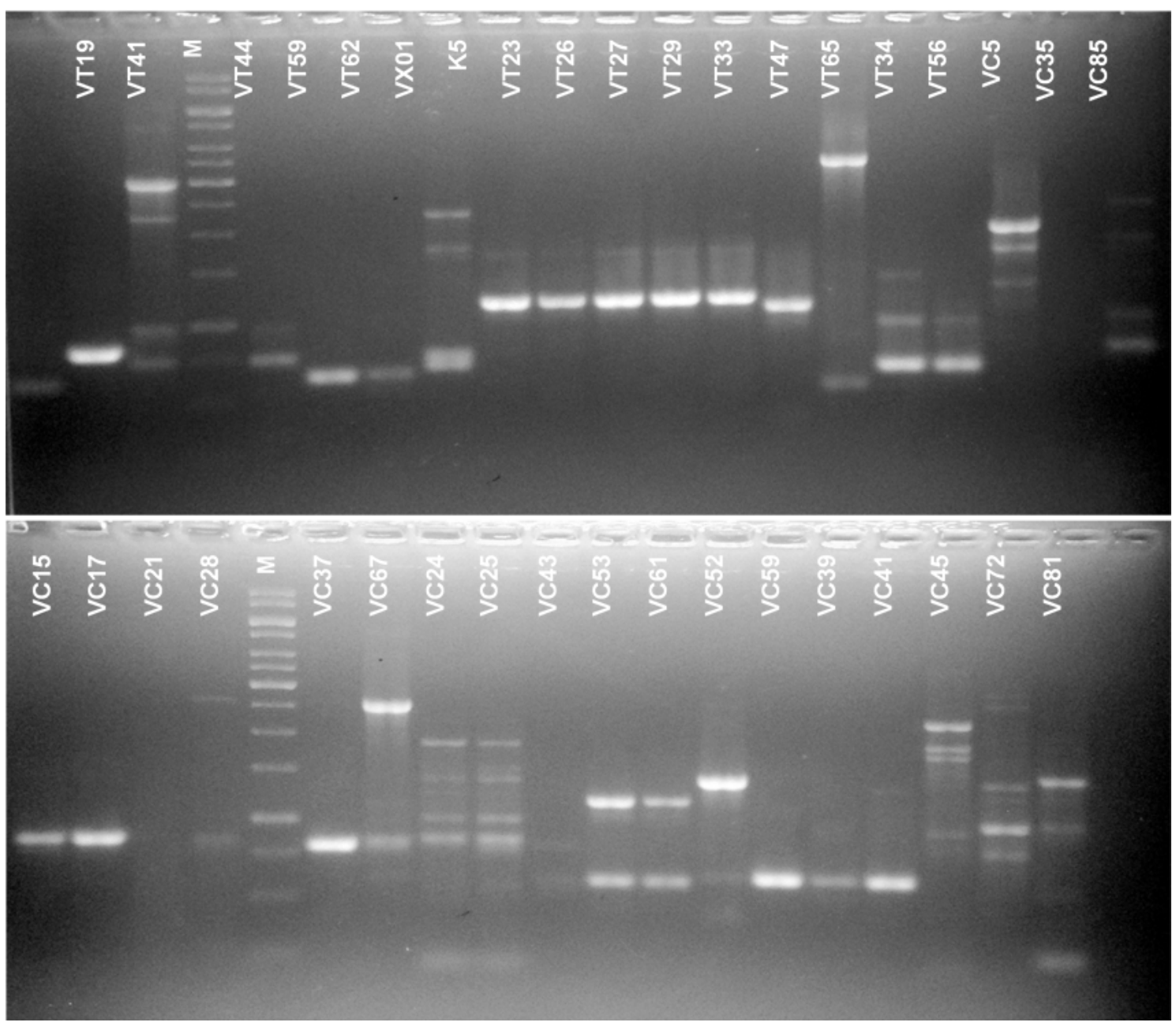

Fig 4. PCR products of OPB-01 primer of 36 samples

and $\mathrm{I}=0.2695)$ ( Table 6).

Table 6. Summary of genetic parameters estimate for 5 species of Vibrio in Thua Thien Hue, Vietnam

\begin{tabular}{lllll}
\hline Populations & na & ne & h & I \\
\hline V. parahaemolyticus & 1.7095 & 1.2440 & 0.1645 & 0.2695 \\
V. vulnificus & 1.4122 & 1.2047 & 0.1247 & 0.1925 \\
V. shilonii & 1.0405 & 1.0221 & 0.0136 & 0.0207 \\
V. harveyi & 1.2838 & 1.1782 & 0.1054 & 0.1574 \\
V. cholerae & 1.2230 & 1.1558 & 0.0885 & 0.1298 \\
Others & 1.6419 & 1.2560 & 0.1719 & 0.2768 \\
Overall & 2.0000 & 1.2885 & 0.2046 & 0.3435 \\
Standard deviation (SD) & 0.0000 & 0.2139 & 0.1195 & 0.1612 \\
\hline
\end{tabular}

The average diversity within populations (Hs) was 0.1114 , which accounted for $51.72 \%$ of the total diversity found in the populations $(\mathrm{Ht}=0.2154)$. The mean coefficient of gene differentiation $(\mathrm{Gst})$ value of 0.4827 indicated a very high degree of genetic differentiation among species. The gene flow $(\mathrm{Nm})$ was 0.5359 , which indicated that it was small among the species ( Table 7).

The values of genetic identity and genetic distance between Vibrio species were given in Table 8 . The analyzed data indicated 
Table 7. Summary analysis of genetic variability across all species ofVibrio in Thua Thien Hue, Vietnam

\begin{tabular}{lllll}
\hline Parameters & Ht & Hs & Gst & Nm \\
\hline Across all populations & 0.2154 & 0.1114 & 0.4827 & 0.5359 \\
SD & & & 0.0176 & 0.0048 \\
\hline
\end{tabular}

that the values of genetic identity between populations were low, ranging from 0.7416 to 0.9545 . V. parahaemolyticus and V. vulnificus had the highest genetic identity (0.9545) while $V$. shilonii and $V$. harveyi had the lowest genetic identity (0.7416). The values of genetic distance between populations were high, varying from 0.0465 to 0.2989 and the two species of $V$. shilonii and $V$. harveyi have the largest genetic distance (0.2989).

Table 8. Nei's (1978) genetic identity (above diagonal) and genetic distance (below diagonal) between 5 species of Vibrio in Thua Thien Hue,

\begin{tabular}{lllllll}
\hline Populations & V. parahaemolyticus & V. vulnificus & V. shilonii & V. harveyi & V. cholerae & Others \\
\hline V. parahaemolyticus & $* * *$ & 0.9545 & 0.8196 & 0.8840 & 0.9024 & 0.9582 \\
V. vulnificus & 0.0465 & $* * * *$ & 0.8375 & 0.8838 & 0.8791 & 0.9474 \\
V. shilonii & 0.1989 & 0.1774 & $\star * * *$ & 0.7416 & 0.7579 & 0.8381 \\
V. harveyi & 0.1233 & 0.1235 & 0.2989 & $* * * *$ & 0.7897 & 0.8670 \\
V. cholerae & 0.1027 & 0.1289 & 0.2772 & 0.2361 & $* * * *$ & 0.8794 \\
Others & 0.0427 & 0.0541 & 0.1766 & 0.1427 & 0.1285 & $* * * *$ \\
\hline
\end{tabular}

\subsection{Cluster analysis}

In the genetic similarity dendrogram constructed on the basis of comparative analysis of the total loci obtained with the ten RAPD primers, the Vibrio species gets distributed based on their genetic distance ( Figure 5). The dendrogram showed that $V$. parahaemolyticus was closely related to $V$. vulnificus whereas $V$. shilonii and $V$. harveyi had large distance.

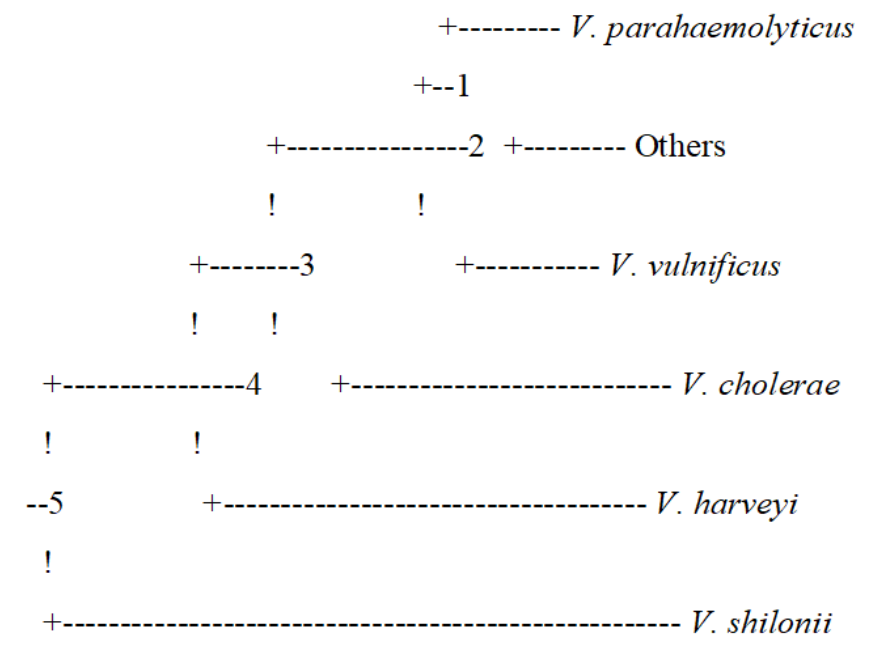

Fig 5. Dendrogram obtained with UPGMA method based on Nei’s (1972) distance for all species of Vibrio in Thua Thien Hue, Vietnam

\section{Conclusion}

In our study, 120 Vibrio samples were isolated from white leg shrimp and fishes cultured in Tam Giang lagoon in Thua Thien Hue province (Vietnam). In shrimp samples, 14/54 strains had pirAvp and pirBvp genes and in fish samples, 18/66 strains had th gene, and none of Vibrio strains had $t d h$ and $t r h$ genes. RAPD analysis of 36 Vibrio samples showed genetic identity between $V$. parahaemolyticus and V. vulnificus is highest while between $V$. shilonii and $V$. harveyi is lowest. V. shilonii had the most different RAPD pattern than other species. 


\section{Acknowledgments}

This study was financial supported by the grant from Vietnam Ministry of Education and Training (Project No. CT-2018-DHH$01)$.

\section{References}

1) Han JE, Tang KFJ, Tran LH, Lightner DV. Photorhabdus insect-related (Pir) toxin-like genes in a plasmid of Vibrio parahaemolyticus, the causative agent of acute hepatopancreatic necrosis disease (AHPND) of shrimp. Diseases of Aquatic Organisms. 2015;113:33-40. doi:10.3354/dao02830.

2) Han JE, Tang KFJ, Piamsomboon P, Pantoja CR. Evaluation of a reliable non-invasive molecular test for the diagnosis of the causative agent of acute hepatopancreatic necrosis disease of shrimp. Aquaculture Reports. 2017;5:58-61. doi:10.1016/j.aqrep.2016.12.004.

3) Sudheesh PS, Al-Ghabshi A, Al-Mazrooei N, Al-Habsi S. Comparative Pathogenomics of Bacteria Causing Infectious Diseases in Fish. International Journal of Evolutionary Biology. 2012;2012:1-16. doi:10.1155/2012/457264.

4) Dard. 2014.

5) Yen P, Van T, Son N, Tram N. Investigation the current situation of fish cage cultured and disease of some economic brackish and marine fish species cultured in Thua Thien Hue Province. Journal of Agriculture and Rural Development. 2019;21:50-57.

6) Behura BB, Samantray BR, Samal SK, Mukherjee SC, Das BK. Use of randomly amplified polymorphic DNA analysis to differentiate Vibrio anguillarum and Vibrio parahaemolyticus. Int J Curr Microbiol App Sci. 2015;4(10):816-828.

7) Mahmud ZH, Kassu A, Mohammad A, Yamato M, Bhuiyan NA, Nair GB, et al. Isolation and molecular characterization of toxigenic Vibrio parahaemolyticus from the Kii Channel, Japan. Microbiological Research. 2006;161(1):25-37. Available from: https://dx.doi.org/10.1016/j.micres.2005.04.005. doi:10.1016/j.micres.2005.04.005.

8) Quang HT, Thoa C, Tan TH, Giang NT, Huy ND, Phuong T. Study on genetic diversity of Paris polyphylla population from Vietnam and China. Plant Cell Biotechnol Mol Biol. 2016;17(1\&2):57-63.

9) Nei M. Genetic Distance between Populations. The American Naturalist. 1972;106(949):283-292. doi:10.1086/282771.

10) Yeh FC, Yang RC, Boyle T, Popgene. Microsoft Windows based freeware for population genetic analysis: Release 1.31, University of Alberta. Edmonton. 1999.

11) Strauss C, Long H, Patterson CE, Te R, Lynch M. Genome-Wide Mutation Rate Response to pH Change in the Coral Reef Pathogen Vibrio shilonii AK1. American Society for Microbiology. 2017. Available from: https://dx.doi.org/10.1128/mbio.01021-17. doi:10.1128/mbio.01021-17.

12) Al-Othrubi SM, Hanafiah A, Radu S, Neoh H, Jamal R. Rapid detection and E-test antimicrobial susceptibility testing of Vibrio parahaemolyticus isolated from seafood and environmental sources in Malaysia. Saudi Med J. 2011;32(4):400-406.

13) Hasrimi AN, Budiharjo A, Jannah SN. Detection of th and tdh genes in Vibrio parahaemolyticus inhabiting farmed water ecosystem used for L. vannamei aquaculture. Journal of Physics: Conference Series. 1025.

14) Chonsin K, Matsuda S, Theethakaew C, Kodama T, Junjhon J, Suzuki Y, et al. Genetic diversity ofVibrio parahaemolyticusstrains isolated from farmed Pacific white shrimp and ambient pond water affected by acute hepatopancreatic necrosis disease outbreak in Thailand. FEMS Microbiology Letters. 2016;363(2):fnv222-fnv222. doi:10.1093/femsle/fnv222.

15) Ahmmed S, Khan MAAK, Eshik MME, Punom NJ, Islam ABMMK, Rahman MS. Genomic and evolutionary features of two AHPND positive Vibrio parahaemolyticus strains isolated from shrimp (Penaeus monodon) of south-west Bangladesh. BMC Microbiology. 2019;19(1). Available from: https: //dx.doi.org/10.1186/s12866-019-1655-8. doi:10.1186/s12866-019-1655-8.

16) Al-Dulaimi MMK, Mutalib SA, Ghani MA, Zaini NAM, Ariffin AA. Multiple Antibiotic Resistance (MAR), Plasmid Profiles, and DNA Polymorphisms among Vibrio vulnificus Isolates. Antibiotics. 2019;8(2):68-68. Available from: https://dx.doi.org/10.3390/antibiotics8020068. doi:10.3390/antibiotics8020068.

17) Giang N, Toan PV, Hung PQ. Hepatopancreatic necrosis syndrome in whiteleg shrimp (Litopenaeus vannamei) farmed in Ninh Thuan. Journal of Sciences and Tachnology in Aquaculture. 2016;1:32-38.

18) Quang NN, Linh NQ, Linh N, Ha TN. Study on hepatopancreas necrosis disease in white shrimp cultured in Thua Thien Hue province. Journal of Agriculture and Rural Development. 2013;17(1):69-76.

19) Restrepo L, Bayot B, Arciniegas S, Bajaña L, Betancourt I, Panchana F, et al. PirVP genes causing AHPND identified in a new Vibrio species (Vibrio punensis) within the commensal Orientalis clade. Springer Science and Business Media LLC. 2018. Available from: https://dx.doi.org/10.1038/s41598018-30903-x. doi:10.1038/s41598-018-30903-x. 